\title{
Human Rights: An Unenforceable Concept
}

DOI: https://doi.org/10.47175/rissj.v3i1.385

\section{| Manotar Tampubolon |}

Faculty of Law, Universitas

Kristen Indonesia, Jakarta, Indonesia

justitie234@gmail.com

\begin{abstract}
This qualitative article analyzes the idea of human rights as inalienable rights. Long before modernity changed the world, it signed many agreements to establish human rights, particularly those governing the boundaries of the authority of leaders and citizens. Although moral assumptions are involved, they have no significant impact on its enforcement. Thus, along with its limited capability, the concept of human rights is solely a decorative element of the constitution and legal framework. Under such circumstances, recognizing the significance of understanding human rights needs an all-out concerted effort, mainly from a universal perspective and a legal enforcement effort. The study seeks to determine why human rights enforcement in Indonesia is ineffective and contrary to the concept of universal human rights. The author employs qualitative research with a descriptive method to address this issue. This research is also desk (library research), as I entirely based it on library data sources on library research. In addition, it employs literature related to the enforcement of Human Rights (HAM) from a legal perspective. This study concludes that human rights enforcement in Indonesia is weak because of flaws in the law and the state's lack of political will to enforce human rights and obligations. These changes include ensuring that the enforcement of human rights is absolute and not influenced by political perspectives and motivations and thus guarantees human freedom. The author suggests that establishing a more effective institution and agency is a more critical step in the coming years

KEYWORDS

Human rights; gross violation; enforcement; political will
\end{abstract}

\section{INTRODUCTION}

Despite the fact that Indonesia has established comprehensive rules to protect human rights, law enforcement remains lax. Indonesia is indeed a rule-of-law country with holistic civil rights protections in the Constitution (UUD 1945), including Law No. 39 of 1999 on human rights and Law No. 20 of 2005 on ICCPR ratification. However, severe human rights violations remain unresolved at the enforcement level, and victims face an uncertain future. Moreover, both state and non-state actors violated human rights in Indonesia. As a result, no one has ever attempted to hold them accountable in court or fulfill the justice for victims.

Indonesia reveals that the constitutionality of fundamental rights is a type of government capable of protecting human rights. Many legal frameworks with a solid commitment to good governance, human rights, and the rule of law have successfully maintained fundamental human rights relations between the state and citizens. However, there are two 
significant points of denial by the government regarding human rights protection in this evaluation. First, the author considers human rights constitutionalism as a defense measure in the absence of legal enforcement. Second, the state cannot protect and fulfill the victims' rights of mass atrocities.

The Human Rights Law contains a long list of recognized human rights that the state must fulfill and protect. This Law recognizes the right to life (Article 9), the right to marry and have children (Article 10), the right to self-development (Articles 11-Article 16), the right to justice (Articles 17-Article 19), the right to personal freedom (Articles 20-Article 27), the right to safety (Articles 28-35), the right to welfare (Articles 36-Article 42), the right to take part in government (Articles 43 (Art 52-Article 56). This Law lacks rights' guarantees, emphasizes the existence of duties, obligations, and primary responsibilities by the government to recognize, safeguard, impose, and protect human rights. According to United Nations (n.d.):

"Human rights are all people's rights, regardless of ethnicity, sexual identity, national origin, nationality, linguistic, faith, or even other social position. Human rights include the right to be free, freedom from oppression and inhumane treatment, freedom of opinion and expression, the right to live and work and schooling, and several others. Everybody else, with no exception, is entitled to all the rights."

Since the concept of human rights enforcement is vague (Joseph \& MecBeth, 2010), it is not easy to make accurate generalizations. The regional and global concept of human rights would be neither cohesive nor monotonic. So for all its brief existence, it established a complex system comprising systems integral to different levels of the ruling power, enforcement power, and techniques. Human rights are basic rights inherent in humans by nature that are universal (Harisman, 2020). However, in the perspective of gross or systematic human rights violations, there are four crucial state obligations: a comprehensive investigation of facts, court proceedings, redress which respect the dignity of every recipient, as well as policy changes of state laws and practices (Evans, 2012). Individuals' right to receive compensatory damages for serious offenses is a necessary counterpoint to such an effective solution for such infringements those who have experienced severe. However, apart from the victim's right to receive reparations, there is a void of state responsibility in fulfilling victims' rights; the national legal framework and the place where victims make claims are ineffective. As a result, these rights cannot be guaranteed completely.

The matter is worse because of severe disagreement among authorities, academics, and organizations about many authorities' proper roles and responsibilities. Several of these fundamental perspectives, engendered by persisting uncertainties about a legitimate mandate, are represented within individual message differences respectively phrases such as "observing," "oversight," "execution," and "implementation."

Considering the previously mentioned issues, this article focuses on why the government cannot redress human rights atrocities in Indonesia and how to resolve those cases. First, this research finds out how the Indonesian government has taken concrete steps to close this gap. Second, by examining government actions that contradict legal pathways, this study contrasts legal norms with upholding human rights. Third, this study focuses on state practice and how law enforcement agencies (National Human Rights Commission, State Attorney general, and the President) have previously served as a foundation for subsequent domestic laws and holistic handling initiatives. Finally, I examine the government's severity, endorsement, and political factors, as this is a critical component of 
the government's reluctance to acknowledge or accept responsibility for protecting individuals of massive human rights violations.

\section{LITERATURE REVIEW}

Legal scholars and other scientists have previously criticized the inefficiency of human rights enforcement. Some argue that enforcement is ineffective because of human rights localization (Durmus, 2020), a narrow understanding of human dignity (Regilme, 2019) and that it is unreal and lacks a universal basis (Jacoub, 2005). Another reason is that most countries only show the hypocrisy and commercial transactions with the most prominent human rights repellents (Dolinger, 2016). Khoury \& Whyte (2021) claim that the principle of protecting human rights is 'hijacked' or misused by corporations. To fulfill the Universalism of human rights requires moral and local cultural values that are consistent with existing human rights principles (Reichert, 2007). Lack of will from certain parties to resolve cases, inadequate legal systems in several countries to prosecute perpetrators, and a political process full of interests are the major obstacles to resolving issues of human rights violations (Amnesty International Indonesia, 2021).

Several researchers offer different perspectives on how to effectively implement the concept of human rights, such as acculturation (Moscrop, 2014) and the role of IGOs in mediating human rights norms for policy actors with the capacity to implement human rights-friendly policies (Regilme, 2014). External pressure on the public to "internationalize" human rights violations is adequate, particularly in countries with authoritarian governments (Gruffydd-Jones, 2019; Meyer \& Thein, 2014; Donelly, 1988; Carraro, 2019). Haglund (2019) claims that institutional designs and judgments by highlegality bodies such as the courts promote human rights, whereas they associated Commission decisions with a higher likelihood of formal complaints. However, the idea of human rights is difficult to implement in Indonesia, including settlement of occurrences of crimes against humanity because of flaws in the law and an unwillingness by the government, particularly the Attorney General's Office, to bring these cases to trial, as previous researchers have overlooked.

\section{RESEARCH METHODS}

The author employs qualitative research with a descriptive-analytical approach. This research is also desk (library research); I entirely based on the data source of this research on library research, which uses literature related to human rights regulatory oversight (HAM). The research method in this paper uses a normative juridical approach because the author takes an inventory of laws and regulations in Individual Rights and the settlement of severe human rights cases and the principle of compensation, human rights cases in Law No. 26 of 2000 concerning Human Rights Court. Using descriptive-analytical research specifications, describe a reality and facts related to the Attorney General's authority to settle human rights violations associated with the rule of law principle.

\section{RESULTS AND DISCUSSION}

As previously stated in severe human rights violations, it is also important to note that state actors typically perpetrated these types of violations, with millions of victims. The table below shows various types of serious violations of individual rights, and even the number of casualties from 1965 till 2020 (table-1). 
Table 1. Gross Human Rights Violations in Indonesia from 1965 to 2020

\begin{tabular}{|l|l|c|c|c|}
\hline \multicolumn{1}{|c|}{ Year } & \multicolumn{1}{|c|}{ Incident } & Actor & $\begin{array}{c}\text { Number } \\
\text { of Victims }\end{array}$ & Legal Process \\
\hline $1965-1966$ & $\begin{array}{l}\text { The 1965 Genocide } \\
\text { (Peristiwa G30 S PKI) }\end{array}$ & State and non-state & $\begin{array}{c}500.000- \\
3.000 .000\end{array}$ & Under Investigation \\
\hline $1982-1985$ & Mysterious Shooting & State & 10.000 & Under Investigation \\
\hline 1988 & Talangsari Tragedy & State & 306 & Under Investigation \\
\hline 1997 & Enforced Disappearance & State & 23 & Under Investigation \\
\hline 1998 & $\begin{array}{l}\text { Trisakti, Semanggi I and } \\
\text { Semanggi II Tragedies }\end{array}$ & State & 235 & Under Investigation \\
\hline 1998 & May Riot & State and Non State & 1.273 & Under Investigation \\
\hline 1999 & $\begin{array}{l}\text { The Aceh KKA Simpang } \\
\text { Incident }\end{array}$ & State & 212 & Under Investigation \\
\hline $1998-1999$ & $\begin{array}{l}\text { Aceh Geudong House } \\
\text { Incident }\end{array}$ & State & 3.504 & Under Investigation \\
\hline $1998-1999$ & $\begin{array}{l}\text { The Shaman Santet } \\
\text { Murder Incident }\end{array}$ & State and Non State & 309 & Under Investigation \\
\hline 2003 & $\begin{array}{l}\text { Jambo Keupok Aceh } \\
\text { Incident }\end{array}$ & State & 21 & Under Investigation \\
\hline 2004 & $\begin{array}{l}\text { Wasior and Wamena } \\
\text { Incident }\end{array}$ & State & 276 & Under Investigation \\
\hline 2020 & Paniai Incident & State & 5 & Under Investigation \\
\hline
\end{tabular}

Source: National Human Rights Commission of the Republic of Indonesia, 2020

The human rights principles in Indonesia are still not functioning perfectly, as per a table of situations of mass atrocities between 1965 and 2020, and are now being investigated. Several factors contribute to the stagnation of human rights conformance, including a weak rule of law and authorities lacking sufficient political will to take positive actions to remedy past human rights atrocities.

\section{Human rights enforcement is hampered by legal flaws.}

The establishment of the Court of Human Rights under Law No. 26 of 2000 was Indonesia's strategy to resolve human rights atrocities. At the very least, some provisions of such a Law allow the reopening of cases of mass atrocities in Indonesia before introducing legislation on the Human Rights Court, as outlined in Articles 43-44 concerning the Ad hoc Human Rights Court. In addition, Article 46 addresses the nullity of expired provisions in cases of grave human rights violations. These provisions are intended to allow cases brought to trial before enacting Law No. 26 of 2000 regarding the Human Rights Court.

According to Section 9 of Legislation No. 26 of 2000 on Human Rights Tribunal, a crime against humanity, as stipulated in Article 7 letter b, is any activity carried out as part of a widespread or systematic attack was directed against the civilian population, such as;
a) killing,
b) annihilation,
c) serfdom,
d) compelled eviction or dislocation of inhabitants,
e) arbitrary denial of freedom" or any other physiological unlawful imprisonment in violation of fundamentals provisions of international Law,
f) torture, 

g) sexual assault, sex slavery, forced prostitution, unplanned parenthood, asepsis or birth control coercion, as well as other comparable forms of sexual exploitation,
h) oppression of a target segment or any other causes universally recognized as illegal under international law,
i) enforced disappearance of persons,
j) racial segregation.,
k) apartheid.

It directly derived the formulation from the Rome Statute's concept. However, in contrast to the concept regulated in the Rome Statute, the concept of crime held in Law No. 26 of 2000 was distorted in its translation, resulting in a fundamental difference between the concepts regulated in the Rome Statute. Crimes against humanity according to International Crimes Database (2013) are defined as follows in Article 7 of the Rome Statute:

"For this Statute, crimes against humanity means any of the following acts when committed as part of a widespread or systematic attack directed against any civilian population, with knowledge of the attack (a):......"

As a result, the concept of crimes against humanity, as stipulated by Law No. 26 of 2000, has several fundamental flaws, namely: First, the term systematic or widespread adopted from the word widespread or systematic is not explained in this law, even though both things are essential to show the unique nature of serious human rights violations, which has implications for the involvement of policies and authorities in the occurrence of offenses. The same rules apply to known elements" (intentions). The three elements' ambiguous definition allows for a variety of interpretations in court. Second, by law no. 26 of 2000, there is an incorrect translation of Article 7 of the Rome Statute, particularly, "directed against any civilian population" phrase, which should be interpreted as "directed against the civilian population," which is equivalent to understanding directly against any civilian population. The word "direct" may imply that only the actors directly in the field are subject to this Article, while the actors above it who make policies are not. Third, the term "resident" rather than "population" has narrowed legal subjects by utilizing territorial boundaries. This has significantly restricted the potential targets of victims of crimes against humanity to citizens of the country where the crime occurred. Another shortcoming explains the offenses mentioned in the formulation of Law No. 26 of 2000. Given that the criminal offenses in this law are particular crimes with very different characteristics than existing public law arrangements, such as the Criminal Code, a sufficiently detailed and clear explanation is essential.

A further legal loophole would be that Legislation No. 26 the Year 2000 formed the Human Rights Court. It asserts that ad hoc Human Rights Court is just a trial notably set in place to probe or decide the case of human rights abuses committed before Law No. 26 of 2000. It means that the prosecution lacks authority to hear cases that involve severe human rights violations committed before passaging Law No. 26 of 2000.

\section{Government lacks of Political Will}

The President's and Attorney General's poor performance has also hampered human rights enforcement and resolving gross human rights violations cases (KONTRAS, 2021). The Attorney General is the highest-ranking official in charge of supervising the prosecutor's roles and responsibilities and acting as an interrogator of serious human rights violations. The theatrics of "returning and forward on," such as case files, persists. The Attorney 
General's Office slides the National Commission of Human Rights (KOMNAS HAM) investigation file to the investigation level caused by a lack of proof. The Attorney General's Office does not issue orders directing the use of coercive measures by investigators (Article 19 paragraph (1) letter g of Law 26/2000). One reason, without a doubt, is insufficient proof or pieces of evidence of human rights abuses.

Another justification given by Attorney General is the lack of an ad hoc Human Rights Tribunal. The determination that cases investigated by KOMNAS HAM did not make up gross human rights violations. The reasons and statements disappointed the victims because the Attorney-General seemed to have no apparent intent of honoring the Constitutional Court's order No. 18/PUU-V/2007 or a way to find guidance on cases of mass atrocities.

Once the Attorney General comes in direct contact with family members of victims upon attempting to make self-defeating statements regarding violations of human rights, the Attorney General's handling of case scenarios worsens (KONTRAS, 2021). Instead of referring cases of gross human rights violations to the Human Rights Court, the Attorney General fought the victim's family to end the abuse. The State Administrative High Court in Jakarta ruled on October 16, 2020, that the statement was illegal, setting a dangerous precedent for the continuation of law enforcement for alleged gross human rights violations in Indonesia (KONTRAS, 2021).

Two additional challenges in uncovering past gross human rights violations cases are the evidence and the shifting scene (Erdianto, 2019). Evidence of decades-old human rights violations may have been lost, and no witnesses remain. However, the National Human Rights Commission (2012) found sufficient evidence during the investigation to show that gross human rights violations occurred during the September 30, 1965 Movement (Gerakan 30 September 1965). The Attorney General must uphold a legal principle in law enforcement, namely equality before the law. This principle is fundamental in a legal system based on the rule of law pattern (Undang-Undang Dasar 1945), which has been transformed into criminal procedural law and is used as a guideline to ensure that everyone follows the applicable legal rules. The principle of equality before the law must be recognized and implemented to enforce human rights. However, based on existing empirical realities, equality before the law is not yet applied in resolving gross human rights violations in Indonesia. It implies that the white-collar crime case-handling system law enforcement uses is still selective.

As a matter of fact of such a state's lack of sincerity, it held no one accountable for past human rights violations. Initially, from 1965 to 2020, neither any offenders of crimes against humanity were held responsible. Moreover, the state also supports abusers of breaches of human rights to strategic positions within the authorities (Amnesty International Indonesia, 2021).

The filed crimes occurred many years ago, making it more difficult to prove because the evidence had been lost, the witnesses' memories were no longer complete or fresh, and many of the witnesses and perpetrators had died. Human Rights violations frequently conceal evidence of these crimes, destroy documents, or issue unwritten orders, as well as simply do what is ordered orally, or intimidate or kill witnesses to obstruct proving the judge. This is an effort to achieve justice, which is difficult to achieve, especially in Indonesia, where the law requires a lot of hard evidence and over one direct witness person against cases brought to court.

However, the prospect of resolving past human rights violations is a long way off. The government-created mechanism can sometimes become a process of impunity for perpetrators. Many issues beset this process, many of which are highly political. The political forces in Indonesia lack or cannot encourage efforts to resolve past human rights 
violations as a prerequisite for transitioning from an authoritarian system to a democratic process. Victim groups and communities require a breakthrough to seize justice for those the state has wronged.

Finally, the mechanism for resolving cases outside of court is the alternative used by most people in Indonesia and worldwide. Penal mediation is a term used in criminal law to refer to alternative dispute resolution outside of the courtroom. An attempt to reform criminal law is made through an out-of-court settlement or penal mediation (penal reform). Criminal law reform (penal reform) essentially encompasses the field of disciplinary policy, which is part of and inextricably linked to law enforcement policy, criminal policy, and social policy.

\section{CONCLUSION}

Human rights are difficult to apply in Indonesia, including completing severe human rights violations cases because of legal flaws and a lack of goodwill on the government, particularly the Attorney General's Office, to bring these perpetrators to justice. The fundamental weakness of Law no. 26 of 2000 concerning the Indonesian Human Rights Court is a change and difference in the concepts contained in Law no. 26 of 2000, where this was caused by an error, either intentionally or unintentionally, in the translation of the concepts contained in the Rome Statute into Law no. 26 of 2000. This mistranslation in the end substantially affected the process of proving the elements of crime of the offense.

This study provides several benefits for both academics and practitioners regarding human rights law and for policymakers to make more effective policies for better protection of rights. First, the focus of research on the concept of human rights in practice is difficult to implement in practice because of the minimal political will from the government and laws that do not support the enforcement of human rights. The author states that the government (especially the Attorney General's Office) is not serious about investigating gross human rights violations. It means that the concept of human rights is difficult to implement when investigators of gross human rights violations are not serious about enforcing human rights law. By taking into account the incomprehensible rules and the non-existent political will of the government, scholars, and practitioners can better understand the influence of law and politics on the enforcement of human rights. Second, ratifying international human rights conventions does not guarantee that a state will comply with international human rights law. This study's findings show that a country's noncompliance with international human rights conventions is apparent. All of this implies that human rights law somehow does not bind the state or government since the state or government loses the political will to implement comprehensive human rights compliance regulations, both for national and international level. In addressing cases of gross violations of human rights that have already happened over the years, the current regime seems to be apprehensive about imposing discriminatory laws towards the victims' rights, favoring postponing the offenders or actors of rights violations from becoming kept legally accountable. These violations, in particular, can only be resolved if there are good intentions and applicable laws in place to enforce the concept of human rights. But, first, the government must establish an institution capable of determining severe human rights issues and compensating victims or their families. If they wait for the process to be completed at the Attorney General's Office, justice for the victims will still be delayed.

\section{REFERENCES}

Amnesty International Indonesia. (2021). Apa itu Pelanggaran HAM Berat? https://www.amnesty.id/apa-itu-pelanggaran-ham-berat/ 
Carraro,V. (2019). Promoting Compliance with Human Rights: The Performance of the United Nations' Universal Periodic Review and Treaty Bodies, International Studies Quarterly, 63(4):1079-1093, https://doi.org/10.1093/isq/sqz078

Commission for the Disappeared and Victims of Violence, "KONTRAS". (2020). September Hitam 2020: Pelanggaran HAM Belum Tuntas, Negara Berdosa. https://kontras.org/wp-content/uploads/2021/10/Final_Catatan-2-Tahun-

Pemerintahan-Jokowi-\%E2\%80\%93-Maaruf-Amin-2.pdf

Dolinger, J. (2016). The Failure of the Universal Declaration of Human Rights, Inter$\begin{array}{llll}\text { American Law } & \text { Review, } & \text { 47(2), }\end{array}$ http://repository.law.miami.edu/umialr/vol47/iss2/4

Donnelly, J. (1988). Human Rights: The Impact of International Action. International Journal, 43(2), 241-263. https://doi.org/10.2307/40202527

Durmuş, E. (2020). A typology of local governments' engagement with human rights: Legal pluralist contributions to international law and human rights. Netherlands Quarterly of Human Rights, 38(1), 30-54. https://doi.org/10.1177/0924051920903241

Erdianto, K. (2019). Jaksa Agung Ungkap Hambatan Penuntasan Kasus Pelanggaran HAM Berat Masa Lalu, Kompas, November 7. https://nasional.kompas.com/read/2019/11/07/16335091/jaksa-agung-ungkaphambatan-penuntasan-kasus-pelanggaran-ham-berat-masa-lalu?page=all .

Evans, C. (2012). The Right to Reparation in International Law for Victims of Armed Conflict, Cambridge: Cambridge University Press.

Gruffydd-Jones, J. J. (2019). Citizens and Condemnation: Strategic Uses of International Human Rights Pressure in Authoritarian States. Comparative Political Studies, 52(4), 579-612. https://doi.org/10.1177/0010414018784066

Haglund, J. (2019). International institutional design and human rights: The case of the Inter-American Human Rights System. Conflict Management and Peace Science, 36(6), 608-625. https://doi.org/10.1177/0738894219881427

Harisman, H. (2020). Community Rights Facing Criminal Law in a Human Rights Perspective. Randwick International of Social Science Journal, 1(2), 264-270. https://doi.org/10.47175/rissj.v1i2.51

Indonesian 1945 Constitution (Undang-Undang Dasar 1945).

International Crimes Database. (2013). Crimes Against Humanity. https://www.internationalcrimesdatabase.org/Crimes/CrimesAgainstHumanity

Komisi Nasional Hak Asasi Manusia Republik Indonesia, “KOMNAS HAM”. (2020). Penyelesaian Proses Hukum atas Kasus Pelanggaran HAM yang Berat, Terhambat. https://www.komnasham.go.id/index.php/news/2020/6/11/1443/penyelesaianproses-hukum-atas-kasus-pelanggaran-ham-yang-berat-terhambat.html

Komisi Nasional Hak Asasi Manusia. (2020). Penyelesaian Proses Hukum atas Kasus Pelanggaran HAM yang Berat, Terhambat. https://www.komnasham.go.id/index.php/news/2020/6/11/1443/penyelesaianproses-hukum-atas-kasus-pelanggaran-ham-yang-berat-terhambat.html

Law of the Republic of Indonesia No. 39 Year 1999 on Human Rights.

Law of the Republic of Indonesia No. 26 Year 2000 on Human Rights Court

Meyer, K. E., \& Thein, H. H. (2014). Business under adverse home country institutions: The case of international sanctions against Myanmar, Journal of World Business, 49(1): 156-171. https://doi.org/10.1016/j.jwb.2013.04.005

Moscrop, H. (2014). Enforcing International Human Rights Law: Problems and Prospects, E-International Relations. https://www.e-ir.info/pdf/48904 
Regilme, S. S. F. (2019). The global politics of human rights: From human rights to human dignity? International Political Science Review, 40(2), 279-290. https://doi.org/10.1177/0192512118757129

Reichert, E. (Ed) (2007). Challenges in Human Rights: A Social Work Perspective. New York: Columbia University Press.

United Nations (.n.d). Human Rights. https://www.un.org/en/global-issues/humanrights

Yacoub, J. (2005). For an Enlargement of Human Rights. Diogenes, 52(2), 79-97. https://doi.org/10.1177/0392192105052632 